\title{
Transition to sustainability reporting: evidence from EU and Ukraine
}

\section{Inna Makarenko}

ACCA DipIFR, Associate Professor, Accounting and Tax Department, Sumy State University, Sumy, Ukraine

\section{Natalie Sirkovska}

ACCA, Audit Manager, Assurance Department, Pricewaterhouse Coopers Audit, Prague, Czech Republic

(C) The Authors, 2017. This article is published with open access at ARMG Publishing.

\begin{abstract}
Sustainable Development Goal of UN (Goal 12.6), the accounting statements of the Association Agreement with the European Union and Section IV of the Deep and Comprehensive Free Trade Area between Ukraine and the EU, Sustainability strategies "Europe - 2020" and "Ukraine - 2020", the provisions of Directive 2014/95/EU are the guidelines for constructing a sustainability reporting system of Ukrainian companies because of the low level of corporate social responsibility perception in the national environment and the need for implementation of European integration initiatives.

Sustainability reporting comparative analysis of European and Ukrainian companies has been performed basing on the GRI data for 1999-2016. This allows us to conclude about proportionality and comparability in the use of research database. However, the results of this study indicate significant differences in the level of sustainability reporting development in Ukraine and the EU. This primarily refers to the number of organizations that make reports and dynamics of disclosure during the period of 1999-2016, company size, industry characteristics and type of applied reporting standards. Based on the analysis carried out the authors formulated the main causes, consequences and trends in national practice of sustainbility disclosure in the context of implementing of Directive 2014/95/EU.
\end{abstract}

This research may contribute to the existing literature in regard identifying key areas of sustainability reporting development in Ukraine on the basis of comparison with the best European experience and its compliance with the requirements of Directive 2014/95/EU.

Among the issues that require further research, we should recall the relationship between the formation of the corporate social responsibility model and sustainability reporting disclosure as well as the influence of the institutional environment. Among the perspective areas of research, the expand of time horizons of analysis for the 2017-2018 years after the publication of the first reports prepared in accordance with the requirements of Directive 2014/95/EU is worth noting.

Limitations of the research carried out concerning the size of the sample of Ukrainian companies were analyzed.

Keywords: sustainability reporting, non-financial information, Directive 2014/95/EU, Association agreement.

JEL Classification: P45.

\section{Introduction}

Sustainable Development Goal of UN (Goal 12.6), the accounting statements of the Association Agreement with the European Union and Section IV of the Deep and Comprehensive Free Trade Area between Ukraine and the EU, Sustainability strategies "Europe - 2020" and "Ukraine - 2020" the provisions of Directive 2014/95/EU on disclosures about non-financial and diversified information by certain large companies and groups, the need of formation the accounting provisions for sustainability reporting (SR) and its audit in Ukrainian companies is actualized.

The category of "non-financial information" is synonymous to SR, as opposed to the financial statements, can form a picture of how the company operates within the economic, social and environmental dimensions of sustainable development. 
SR acquires particular importance in the context of restoring confidence in the business, meeting the information needs of different categories of stakeholders of Ukrainian companies, increasing the transparency of their activities in order to reach the European markets of goods and services, providing competitive products, high standards of quality and safety of activities and increasing investment attractiveness.

The fundamental document defining the need, options and formats of SR submission in the EU is Directive 2014/95/EU. Its value lies in creating a framework for information disclosure that would enable you to measure, monitor and manage companies' activities and effect the dimensions of sustainable development, identify risks for sustainable development and ensure the confidence of investors and consumers "towards a sustainable global economy by combining long-term profitability with social justice and environmental protection".

The rules of Directive 2014/95/EU are the guidelines for constructing a sustainability reporting system of Ukrainian companies because of the low level of corporate social responsibility (CSR) perception in the national environment and the need for implementation of European integration initiatives. The questions of its use are widely reflected in the works of foreign scholars, while in the domestic scientific community they do not have sufficient lighting.

The aim of the article is to carry out a comparative analysis of non-financial information disclosure in the EU and Ukraine in the light of the requirements of Directive 2014/95/EU.

SR comparative analysis of European and Ukrainian companies has been performed based on the GRI data. This allows us to conclude about proportionality and comparability in the use of research database. However, the results of this study indicate significant differences in the level of SR development in Ukraine and the EU. This primarily refers to the number of organizations that make reports and dynamics of disclosure during the period of 1999-2016, company size, industry characteristics and type of applied reporting standards. The authors concluded that despite the mandatory provisions of Directive 2014/95/EU for public interest entities and large companies in the EU, SR share of small and medium companies deserves attention as well. However, the lack of small and medium-sized companies among Ukrainian organizations that make reports is an evidence of low-level perception of CSR in Ukrainian business.

A key problem that characterizes the SR system of Ukrainian companies in general (regardless of individual leaders - MNE) lies in the fact that not only willing mechanisms for SR that meet the provisions of Directive 2014/95/EU, but the system of CSR business at the national level is immature.

The authors formulated the main causes, consequences and trends of formation of national foundations for SR disclosure in the context of implementing the rules of Directive 2014/95/EU.

The structure of the article is organized as follows: the first section is an overview of the requirements of normative sources on the organization of SR in accordance with Directive 2014/95/EU, the second section an overview of academic sources, the third - the practical experience of the SR system functioning in Ukraine and the EU, the fourth - conclusions and closing remarks.

\section{Regulator's requirements}

A mainstream in global governance processes and social development is the concept of sustainable development, the targets of which are formalized at the UN sustainable development goals. SR is a communication basis for evaluating progress in achieving these goals stands. The strategy "Europe - 2020" and a sustainable development strategy "Ukraine - 2020" are declarative documents to achieve energy efficient, sustainable, innovative and competitive economy and these objectives. One of the areas of the EU strategy in the part of promoting CSR policy is to improve the disclosure of social and environmental information that corresponds to the objectives of sustainable development of the UN 12.6.

It presupposes the implementation of sustainable development reporting worldwide and support of responsible business practices by measurement and disclosure of environmental and social impacts. In this context, reporting on sustainable development is seen as a key tool for promoting the private sector contribution to global development. According to the Global Reporting Initiative as a leading organization dedicated to SR standardization, starting from 2000 over 7600 largest companies in the world already issued 27,406 reports which in some extent reveal the social, environmental dimensions of sustainable development. A big part of these reports (3747 organizations from 8238 reports) belong to the EU companies. 
The adoption on the $6^{\text {th }}$ of December, 2014 and publication in the Official Journal of the European Union on the $15^{\text {th }}$ of December, 2015 of the Directive 2014/95/EU on the disclosure of non-financial and diversity information by certain large undertakings and groups obliged the member states to join on the highest legislative level through the mechanisms of sustainability development disclosure performing objectives 12.6 and strategy "Europe - 2020".

Some EU countries, including UK, France and Denmark are among the first which joined these initiatives. For example, The Companies Act in the UK has a requirement to disclose information about GHG emission in the annual report. The Grenelle II Act in France requires from large public and listed companies a report on CSR in the annual management report and starting from 2016 in a mandatory way establishes disclosures about climate change. More than 1100 of Denmark's largest companies are accountable for CSR, especially regarding climate change and human rights in the annual reports. In Spain, the Spanish Sustainability economy Law (2011) and in Italy Mandatory ESG disclosure and investment policy (2012) set mandatory requirements for disclosure of non-financial information by pension funds (Carrots \& Sticks, 2016).

Directive 2014/95/EU contains amendments to Directive 2013/34/EU about the annual financial statements, consolidated financial statements and related reports of certain types of companies and must be transposed into national law of the member states starting from the $1^{\text {st }}$ of January, 2017 or during 2017. Thus, the first reports, as required by Directive 2014/95/EU, are expected to be published in 2018 for the 2017-2018 fiscal year.

Under the Association Agreement with the EU from the $27^{\text {th }}$ of June, 2014, Ukraine during the same period (from 2017) undertook the obligation to implement European law norms into national practice. In particular, this applies to changes in accounting, reporting and auditing. Besides the implementation of corporate governance principles of the OECD and the paragraph "b" of the Article 387 of the Chapter 13 Company Law, Corporate Governance, Accounting and Auditing on the implementation of nationally appropriate international standards and gradual approximation to the EU law in the field of accounting and auditing, a direct impact on the transition to the SR in Ukraine have the provisions of the Article 293 Trade favouring sustainable development (Chapter 13 Trade and Sustainable Development).

In Article 293 the decisive role of sustainable development conception, CSR principles and accountability in the relations between the EU and Ukraine is established, which essentially obliges the Ukrainian enterprises to adopt responsible business practices and disclosure of sustainable development of European contractors for the purpose of entering new markets and promoting their products.

Despite the fact that Directive 2014/95/EU had been already adopted after the signing of the Association Agreement, given that Article, it gains a special importance, in particular because of the lack of national legislative counterparts and spread among the limited number of companies of voluntary disclosure of CSR and sustainable development.

Directive 2014/95/EU is primarily aimed at increasing the transparency of large companies on the European area as for non-financial information on sustainable development, ensuring its quality and comparability. The scope of the Directive primarily involves large entities of public interest. They are:

1) listed companies, banks, insurance undertakings and other companies that are so designated by Member States with more than 500 employees, a balance sheet total of 20 million Euros or a net total of 40 million Euros, and that are listed on a EU regulated exchange market;

2) companies with more than 500 employees, a balance sheet total of 20 million Euros or a net total of 40 million Euros, and that are not listed on a EU regulated exchange market but are so designated by Member States as socially important (including banks, insurance companies).

Taking into account the leading principle of the Directive "report or explain", disclosure of non-financial information on sustainable development is expected by companies only on relevant and significant aspects of their policies and strategies on CSR and due diligence, the description of existing business models and their outcomes, significant risks relating to companies and activities of risk management in terms of the following aspects:

$>$ environmental matters,

$>$ social and employee aspects,

$>$ respect for human rights,

$>$ anticorruption and bribery issues, and

$>$ diversity in their board of directors. 
Some examples of information on each of the aspects are listed in Table 1.

Table 1. Examples of information on each of the aspects

\begin{tabular}{|c|c|}
\hline Aspects & Examples \\
\hline \multirow{6}{*}{ Environmental matters } & Current and foreseeable environmental impacts \\
\hline & Health and safety impacts, as appropriate \\
\hline & Use of renewable energy and/or non-renewable energy \\
\hline & Greenhouse gas emissions \\
\hline & Water use \\
\hline & Air pollution \\
\hline \multirow{7}{*}{ Social and employee aspects } & Actions taken to ensure gender equality \\
\hline & Implementation of fundamental conventions of the International Labor Organization \\
\hline & Working conditions \\
\hline & Social dialogue and dialogue with local communities \\
\hline & Respect of the right of workers to be informed and consulted \\
\hline & Respect of trade union rights \\
\hline & Health and safety at work \\
\hline Respect for human rights & Information on the prevention of human rights abuses \\
\hline Anticorruption and bribery issues & Information in instruments in place to fight corruption and bribery \\
\hline Diversity in board of directors & $\begin{array}{l}\text { Different types of disclosures about age, education, profession concerning administrative, } \\
\text { management and supervisory bodies }\end{array}$ \\
\hline
\end{tabular}

The provisions of Directive 2014/95/EU which has a non-regulatory nature is quite flexible in the choice of the national or international guidelines for SR or CSR policy formation. Among the main Guidelines and Principles on which the Commission's CSR strategy is built the following ones can be named: United Nations Global Compact, United Nations Guiding Principles on Business and Human Rights, ISO 26000 Guidance Standard on Social Responsibility, International Labor Organization Tripartite Declaration of Principles concerning Multinational Enterprises on Social Policy, OECD Guidelines for Multinational Enterprises, Guidelines of Global Reporting Initiative, OECD Due Diligence Guidance for Responsible Supply Chains of Minerals from Conflict-Affected and High-Risk Areas, EMAS etc.

\section{Literature review}

Systematic nature of the implementation of initiatives on CSR, achieving goals of sustainable development by European companies give the SR a significance and acknowledgment from stakeholders.

A comparative analysis of the Directive 2014/95/EU on the best practice of non-financial reporting presentation and its development prospects are described in the work of Szabó and Sørensen (2015). In later work of these authors (Szabó and Sørensen (2016)) the procedure and barriers to implementation of the Directive in groups of companies are discussed in detail.

Sectoral context in implementing the Directive 2014/95/EU is the subject of research by Doni, Gasperini.

The features of formation and submission SR in some EU member states are highlighted in the works of Filipova-Slancheva (2015) - Bulgaria, Skouloudis, Evangelinos, Kourmousis (2010) - Greece, Delbard (2008) - France, Vuontisjärvi (2006) - Finland, Fifka and Drabble (2012) - the UK and Finland, Idowu, Towler, (2004) - the UK.

A comparative analysis of regulatory demands to reporting on sustainable development and national policies of CSR among the EU member states like Denmark, Sweden, UK, France, the Netherlands was held by Hąbek and Wolniak (2013).

The problems of regulatory implementation process of the Directive 2014/95/EU in the context of the overall EU policy in the field of CSR are considered in the work of Monciardini D. (2016), specific feature of its implementation with meeting the requirements of national legislation, particularly in Germany - in the work of Kinderman (2015).

Cross-cultural comparative analysis of CSR policy on the example of the largest corporations in the US and EU Hartman, Rubin, Dhanda (2007) shows that transnational companies of EU, unlike the United States use 
the theory of citizenship, corporate accountability and moral obligations relying on both financial and sustainability elements in justifying their CSR activities. Moreover, efforts to regulate CSR reporting are more advanced in the EU (Tschopp (2005)).

However, Hąbek and Wolniak (2016) denoted low quality of SR companies in selected member countries. The authors note that in the analyzed reports the relevance of revealed elements is higher than their reliability.

Consequently, in the European scientific community SR issues and performance of the Directive 2014/95/EU norms have a wide coverage at different levels: at the level of member states, individual industries, the level of total EU strategy on CSR and within regulatory policy, cross-cultural comparison. The question of disclosure of non-financial information in the context of implementation of the Directive 2014/95/EU rules is not enough covered. Some aspects of convergent processes in financial reporting submission and its audit are disclosed in the works of Golov (2014), Zubilevich (2014), Parkhomenko (2014), Petryk (2014). In general, the study of SR of Ukrainian companies requires a systematic approach because of the necessity of implementing the rules of the Directive 2014/95/EU.

\section{Empirical evidence}

An empirical study of SR European and Ukrainian companies was conducted based on the most complete and comparable aspects of reports GRI, published since 1999. Given the dynamic nature of the base, we should note that all the data are collected as of November $1^{\text {st }}, 2016$.

Authors selected 3747 organizations from the EU member countries for continuous study, that have published 8238 reports and 28 Ukrainian companies which have published 47 reports for the period.

Comparative analysis of SR of companies from EU and Ukraine was conducted according to the following areas:

$>$ analysis of the number of reports on sustainable development in dynamics;

$>$ sector and size of companies that make reports;

$>$ prevailing type of accounting standards.

In the first area of analysis (Figure 1) the entire incomparability of SR in Ukraine and the EU in terms of reporting scope is worth noting. Dynamics of reporting on SD by European companies has a significant growing trend - beginning with the first three reports published by British Airways, Procter \& Gamble, Netherlands and Svenska Cellulosa Aktiebolaget - SCA in 1999, their number increased by 386 times. In 2014-2015, 1145 European organizations published 1158 reports on SD. The number of reports for 2016 in this context cannot be considered as indicative, because usually preparation process of SR lasts about a year, or may cover several financial years. The 2017-2018 fiscal year should be very interesting to observe, as European companies must submit the first non-financial statements under the requirements of Directive 2014/95/EU.

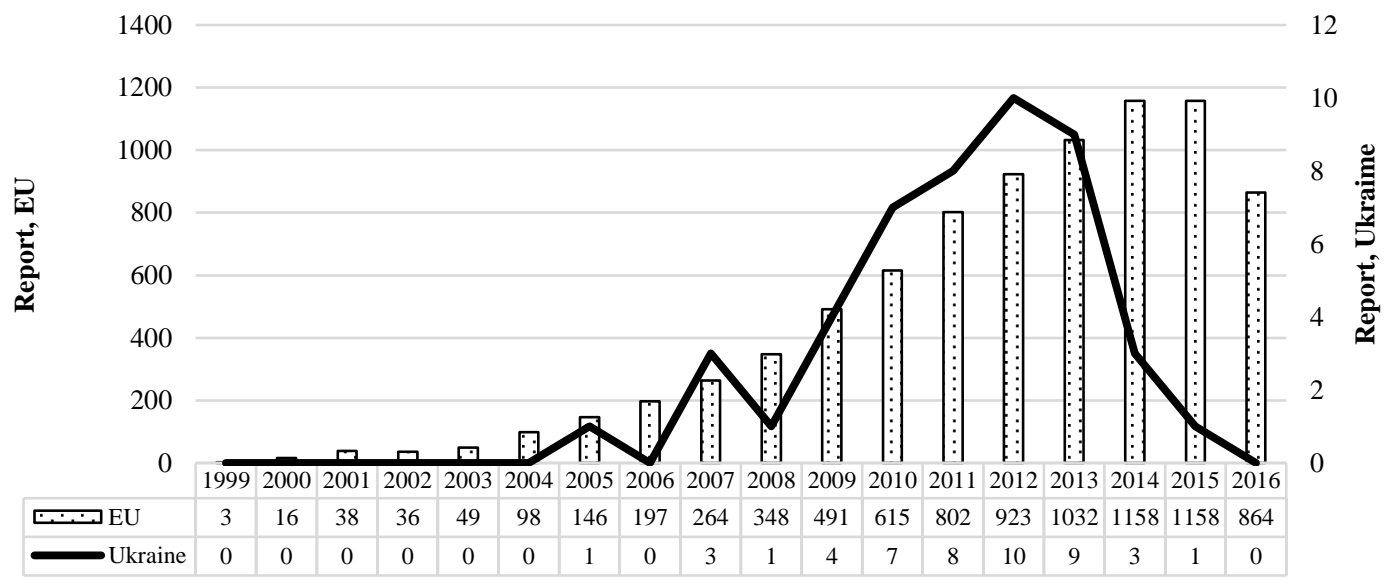

Figure 1. The number of SR in the EU and Ukraine for the period of 1999-2016.

Source: compiled by the author according to GRI data http://database.globalreporting.org/search/

In Ukraine, the appearance of the first SR starts from 2005. Since then till 2016, 28 companies have published 47 reports, the maximum number of which is submitted in 2010-2013. Pioneers in drawing SR in Ukraine are 
the companies VidiGroup (2005), DTEK (2007) and Kyivstar (2007), and a decreased activity of companies in recent years, except for reasons related to accounting cycle and peculiarities of SR preparation can be explained by complex economic and political situation in the country. It directly affects major companies from the East of Ukraine, which have traditionally been leaders in the SR.

Sectorial comparison of SR in the EU and Ukraine shows some similarities: the main sectors of origin of reporters are food and beverage products, metals products, agriculture, financial services, houshold products and other.

This is due to the presence in the sample of reports a significant number of multinational corporations, global financial institutions and organizations that carry out their activities in the markets of different countries.

In the comparison of SR in the EU and Ukraine, according to the size of reporting companies, we found a significant feature that indicates a significant interest in the concepts of CSR and SD of different in size EU companies - from multinational corporations (21.8\%), large companies (64.1\%) to small and medium businesses $(14,1 \%)$ of all organizations whose reports are submitted to GRI. It should be noted that the implementation of provisions of Directive 2014/95/EU for the first two categories of companies will not be of significant difficulties - as European large and multinational companies voluntarily disclose information on the dimensions of sustainable development and use one of the foundations mentioned in Directive for SR and CSR, first of all Standards and Guidelines of GRI.

Despite the fact that Directive 2014/95/EU is applied directly only to 6000 of all EU companies, but these are the companies that have a significant impact on society and sustainable development in size, total assets, activities, networks of relationships with stakeholders.

In Ukraine the formal provisions of Directive 2014/95/EU are fulfilled by the largest companies which obviously have the greatest impact and opportunities for promoting sustainable development initiatives by means of reporting. At the same time, a large proportion of SME reports, published by European companies, in contrast to the total absence of this segment of Ukrainian business at GRI base additionally indicate the low prevalence and perceptions of CSR and sustainable development in the ideology of Ukrainian society.

As for the specific of SR preparation, in the EU the GRI approach is prevailing - only $20.2 \%$ of reports are compiled by other standards (Table 2). At the same time, the GRI system in Ukraine by the number of companies supporters $(59.6 \%)$ is slightly higher than companies using free-form reporting $(40.4 \%)$. Given the focus of reports of Ukrainian companies in 2010-2013 years, the most used is GRI-G3 standard. The last of the applicable standards in Ukraine is GRI-G4, a reference to which in their reports was provided only by Ernst \& Young, Kernel and Obolon.

Table 2. Standards for SR preparation in the EU and Ukraine in 1999-2016

\begin{tabular}{|c|c|c|c|c|c|c|}
\hline \multirow{2}{*}{ Reporting standards } & \multicolumn{3}{|c|}{ EU } & \multicolumn{3}{|c|}{ Ukraine } \\
\hline & Organization & Reports & $\%$ & Organization & Reports & $\%$ \\
\hline GRI-G1 & 61 & 86 & 1.0 & - & - & - \\
\hline GRI-G2 & 241 & 465 & 5.6 & - & - & - \\
\hline GRI-G3 & 1023 & 3021 & 36.7 & 10 & 20 & 42.6 \\
\hline GRI-G3.1 & 612 & 1171 & 14.2 & - & - & - \\
\hline GRI-G4 & 713 & 1155 & 14.0 & 3 & 3 & 6.4 \\
\hline GRI-referenced & 312 & 510 & 6.2 & 5 & 5 & 10.6 \\
\hline Non GRI & 785 & 1830 & 22.2 & 10 & 19 & 40.4 \\
\hline Total & 3747 & 8238 & 100.00 & 28 & 47 & 100.0 \\
\hline
\end{tabular}

Source: compiled by the author according to GRI data http://database.globalreporting.org/search/

Besides the studied reporting standards, the continuous research of published reports by Ukrainian companies in the part of chosen CSR standards leads to the conclusion that UNGC is the main type among them. The disclosure of 10 basic principles of contract in communication report on the progress of a SR form is a char- 
acteristic for $83.0 \%$ of Ukrainian companies, while the EU companies apply a broader basis for CSR standardization. However, formally, Ukrainian companies-members of the Global Compact comply with Directive 2014/95/EU as for a selected basis for standardization of their CSR initiatives.

Particular attention should be paid to the integrated presentation format of SR and financial reporting: only in Obolon report for 2014 its compliance with IIRC requirements is declared.

Summing up, it should be noted that, compared to the EU companies, minimum SR number of Ukrainian companies, in our opinion, exists due to a low level of spread and perception of CSR among them and due to the lack of a single national framework for its development in general, as well as accounting methodology of $\mathrm{SD}$ in particular. A detailed analysis of causes, consequences and trends of formation of national foundations of SR disclosure in the context of implementing rules of Directive 2014/95/EU is carried out in the final part of the article.

\section{Conclusion and remarks}

The consideration of SR practice of Ukrainian and European companies in the light of the implementation of the Directive 2014/95/EU rules led to the conclusion about the low level of understanding, acceptance and use in the current activities of companies of disclosing non-financial information on dimensions of sustainable development.

Hence, there is a terminology indefiniteness - even reports are called by companies quite differently (a social report, a corporate responsibility report, a corporate social responsibility report, a non-financial report, a report on progress, SR) and publication of SR is made only by the largest companies oriented to foreign capital markets or by local companies - participants of MNEs.

A search for reasons for this situation allowed us to group the key factors that prevent mass disclosure on SR by Ukrainian companies, in the following way:

$>$ informalization of existing since the Soviet times social and environmental initiatives in a single direction of CSR. The practice of realization of separate social and environmental initiatives has a chaotic and fragmented nature. The lack of consistency in the implementation of the specific areas of CSR by Ukrainian companies creates a picture of the lack of such an activity;

$>$ lack of understanding at the level of top management of the need and benefits of CSR and SR as a tool to achieve the strategic goals of companies with regard to implicit relationship in Ukraine between the use of CSR practices, disclosure of SR and financial performance of companies;

$>$ immaturity of national CSR model, its institutional provisions at various levels - from national (at the core economic ministries, embodied in the CSR strategy) to the level of individual companies and their business strategies.

$>$ immaturity of institutions and stakeholder management practices in business - lack of demand for nonfinancial information by major categories of users. Information requests as for dimensions of sustainable development to companies from the local community, customers, employees are minimized and limited by implementation of minimum regulatory requirements;

$>$ deformed structure of reporting in general - an offset of efforts to disclose information about the company toward financial, primarily tax reporting;

$>$ lack of accounting and methodological provision of reporting indicators for the dimensions of sustainable development, accessible and understandable guidance on the SR compilation;

$>$ lack of funds to finance companies with CSR initiatives and activities to form accounting provisions of their disclosure in SR, operational, technical and information support of SR;

$>$ features of the socio-cultural environment and mentality of Ukrainians, who have no clear understanding of business responsibility to society and the need to implement sustainable development initiatives.

The consequences of low-level perception of CSR and the level of its coverage in the SR of Ukrainian companies have a low level of loyalty and confidence in the business environment that promotes the outflow of best staff abroad, low motivation to work, reducing the innovation potential of the economy and irrational use of natural resources.

Particular emphasis should be done on a shortfall in benefits from increased competitiveness, investment attractiveness and recognition of Ukrainian business abroad and entering new goods and financial markets in 
the absence of a clear CSR policy and quality, accurate SR. The loss of business competitiveness reduces the competitiveness of the country as a whole, does not allow it to use the integration potential.

The basic direction to overcome the negative aspects of implementing CSR activities in Ukraine and SR disclosure is the creation of an institutional framework at the highest legislative level, which can be formalized in national CSR strategy. Despite some attempts to develop it, so far there is no coherent policy for Ukrainian companies in the field of sustainable development. For those companies whose participation in the CSR is not yet the norm (apart from the largest companies considered in Ukraine) regulatory requirements may become a push for CSR activities. In connection with this, we offer to formulate them on the basis of the rules of Directive 2014/95/EU. The development of methodological guidance on the application of advanced global approaches to CSR implementation and presentation of non-financial information, specified in the Directive, will form the basis for accounting provisions of SR in Ukraine.

It is obvious that the rules for the implementation of that Directive in national environment are uncontested due to the adopted vector of European integration.

The use of regulatory tools must be complemented by the intensification of mass information activities to spread the knowledge of the concept of sustainable development among the broadest social circles: people, business environment, management and power to shape national consciousness and perception of the need for responsible business.

Another issue in the implementing rules of Directive 2014/95/EU in Ukraine is identification of large or PIEs companies, for which the requirements for the presentation of non-financial information are mandatory.

In addition to the mandatory institutional disclosure requirements of SR by large Ukrainian companies we offer (considering the European practice) to complement their list by PIEs such as banks, insurance companies, institutions of financial services market, listed companies, state-owned companies. As the basis we can take the rules of the Law of Ukraine "On Accounting and Financial Reporting" and the Order of Presentation of Financial Statements of the Cabinet of Ministers of Ukraine, which clearly set a list of companies reporting according IFRS.

We consider it is necessary to join the process of formation of the drafting and presentation of SR of Ukrainian companies and financial institutions of key regulators - the National Bank of Ukraine, the National Commission on Securities and Stock Market, which would from their part create a momentum and form the specific requirements for the disclosure of non-financial information by accountable to them subjects of management.

A separate line in promoting SR among Ukrainian companies is the increasing of participation of the Audit Chamber of Ukraine and Audit Community of Ukraine in light of the convergence process of harmonization of legal regulation of the audit, in particular the provisions of Directive 2014/56/EU "On statutory audits of annual and consolidated statements” and EU Regulation № 537/2014 "On specific requirements regarding statutory audit of public inetest entities".

Among the issues that require further resolution, we must recall the relationship between the perception of CSR in Ukrainian business environment, the chosen model of CSR, socio-cultural factors and activity of companies in disclosure on sustainable development. In addition, the influence of institutional environment and mandatory requirements of governments and stock markets on the development of CSR and SR need a detailed attention despite voluntary disclosure practice.

Among the perspective areas of research the analysis of the SR dynamics of European companies after 20172018, after the publication of the first reports, prepared in accordance with the requirements of the Directive, are worth noting.

Limitations of the research carried out concerning the size of the sample of Ukrainian companies were analyzed.

\section{References}

1. Delbard, O. (2008). CSR legislation in France and the European regulatory paradox: an analysis of EU CSR policy and sustainability reporting practice, Corporate Governance: The international journal of business in society, 8: (4), 397-405. Retrived from: DOI http://dx.doi.org/10.1108/14720700810899149.

2. Directive 2014/56/EU “On statutory audits of annual accounts and consolidated accounts". Retrieved from http://eur-lex.europa.eu/legal-content/EN/TXT/?uri=celex\%3A32014L0056. 
3. Directive 2014/95/EU of the European Parliament and the Council of 22 October 2014 amending Directive 2013/34/EU as regards disclosure of non financial and diversity information by certain large undertakings and groups, Official Journal of the European Union L 330/1. Retrieved from http://eur-lex.europa.eu/legal-content/EN/TXT/?uri=CELEX:32014L0095.

4. EU-Ukraine Association Agreement 27.06.2014. Retrieved from http://eeas.europa.eu/archives/ delegations/ukraine/eu_ukraine/association_agreement/index_en.htm.

5. Fifka, M.S. and Drabble, M. (2012). Focus and Standardization of Sustainability Reporting - A Comparative Study of the United Kingdom and Finland. Retrived from doi:10.1002/bse.1730.

6. Filipova-Slancheva, A. (2015). Non-financial Reporting in Bulgaria - Status and Challenges. Retrived from doi: 10.18638/hassacc.2015.3.1.163

7. Gasperini, A., \& Doni, F. (2015). Sustainability Reporting and Value Relevance: Empirical Evidence from the Beverage Industry. In IFKAD 2015 International Forum on Knowledge Asset Dynamics. 10-12 June 2015. Bari Italy Culture, Innovation and Entrepreneurship: Connecting the Knowledge Dots. PROCEEDINGS (pp. 551-566). Matera: IFKAD.

8. Hąbek, P. \& Wolniak, R. (2016) Assessing the quality of corporate social responsibility reports: the case of reporting practices in selected European Union member states. Quality and Quantity. Retrived from doi:10.1007/s11135-014-0155-z.

9. Hartman, L.P., Rubin, R.S. \& Dhanda, K.K. (2007). The Communication of Corporate Social Responsibility: United States and European Union Multinational Corporations. Journal of Business, 74, (4), Ethics in and of Global Organizations: The EBEN 19th Annual Conference in Vienna (Sep., 2007), pp. 373-389.

10. Holov, S. (2014). Rehulyuvannya bukhhalters'koho obliku i audytu v YeS ta vyklyky dlya Ukrayiny, [The regulation of accounting and auditing in the EU and calls for Ukraine] Bukhhalters 'kyy oblik $i$ audyt, 10, 3-13. (in Ukrainian).

11. Idowu S.O., Towler B.A. (2004). A comparative study of the contents of corporate social responsibility reports of UK companies. Management of Environmental Quality: An International Journal, 15 (4), 420-437.

12. Kinderman, Daniel P. (2015). The Struggle Over the EU Non-Financial Disclosure Directive (June 1, 2015). WSI-Mitteilungen 8/2015, 613-621.

13. Monciardini D. (2015). The 'Coalition of the Unlikely' Driving the EU Regulatory Process of Non-Financial Reporting. Social and Environmental Accountability Journal 36, (1): EU Regulation of Corporate Social and Environmental Reporting, 76-89.

14. Parkhomenko, V. (2014), Yevrokonverhentsiya bukhhalters'koho obliku [Euroconvergence of accounting], Bukhhalters'kyy oblik $i$ audyt, 2014, No 8, pp. 3-4 (in Ukrainian).

15. Hąbek, P. and Wolniak, R. (2013). Analysis of the approaches to CSR reporting in selected European Union countries. International Journal of Economics and Research, 4 (6), 79-95.

16. Petryk, O.A. (2011). Problemy adaptatsii zakonodavstva u sferi audyta do polozhen 43 Dyrektyvy YeS ta Zelenoi knyhy "Polityka audytu: uroky kryzy" [The problem of adaptations the legislation to audit provisions CHZ EU Directive and the Green Paper "Audit Policy: Lessons from the crisis"]. Visnyk Lvivskoi Komertsiinoi Akademii, 265-268 (in Ukrainian).

17. Skouloudis, A., Evangelinos K., Kourmousis, F. (2010). Assessing non-financial reports according to the Global Reporting Initiative Guidelines: Evidence From Greece. Journal of Cleaner Production, $18(5), 426-438$

18. Szabó, D.G. and Sørensen, K.E. (2015). New EU Directive on the Disclosure of Non-Financial Information (CSR). European Company and Financial Law Review, 12 (3), 307-340.

19. Szabó, D.G. and Sørensen, K.E. (2016). Non-Financial Reporting, CSR Frameworks and Groups of Undertakings - Application and Consequences (September 19, 2016). Nordic \& European Company Law Working Paper No. 16-01. Retrieved from https://ssrn.com/abstract=2774170

20. Vander Bauwhede, Heidi and Willekens, Marleen, (2008), Disclosure on Corporate Governance in the European Union. Corporate Governance: An International Review, 16 (2), 101-115.

21. Vuontisjärvi, T. (2006). Corporate Social Reporting in the European Context and Human Resource Disclosures: An Analysis of Finnish Companies. Journal of Business Ethics, 69 (4), 331-354.

22. Zubilevych, S. (2014). Oblikova Dyrektyva YeS, yiyi vplyv na sklad i zmist zvitiv yevropeys'kykh kompaniy ta perspektyvy dlya Ukrayiny [EU accounting directive and its impact on the structure and content of the reports of European companies and the prospects for Ukraine], Bukhhalters'kyy oblik $i$ audyt, 7, 315 (in Ukrainian). 